\title{
Comparative Use of Soil Organic and Inorganic Amendments in Heavy Metals Stabilization
}

\author{
Agustina Branzini and Marta Susana Zubillaga \\ Department of Fertility and Fertilizers, University of Buenos Aires, Avenue San Martín 4453, 1417 Buenos Aires, Argentina \\ Correspondence should be addressed to Agustina Branzini, branzini@agro.uba.ar
}

Received 21 October 2011; Revised 20 January 2012; Accepted 25 January 2012

Academic Editor: Giancarlo Renella

Copyright (C) 2012 A. Branzini and M. S. Zubillaga. This is an open access article distributed under the Creative Commons Attribution License, which permits unrestricted use, distribution, and reproduction in any medium, provided the original work is properly cited.

\begin{abstract}
Remediation strategies are capable to mitigate negative effects of heavy metals (HMs) on soils. The distribution of cooper (Cu), zinc $(\mathrm{Zn})$, and chromium (Cr) was evaluated in a contaminated soil after adding biosolid compost (BC) and phosphate fertilizer (PF). A greenhouse assay and sequential extraction procedure were performed to determine the fractionation of HM in contaminated and remediated soil. In $\mathrm{BC}$ treatment, among 4 to $6 \%$ of $\mathrm{Cu}$ was associated with soil humic substances. Without amendments and with fertilizer application, $\mathrm{Zn}$ solubility increased by 15.4 and $8.4 \%$, respectively, with experiment time. Although Cr was significantly adsorbed to the inorganic fraction, with compost application there was a transfer to organic fraction. A single amendment application is not suitable for immobilizing all metals of concern, because there are diverse union's behaviors between $\mathrm{HM}$ and soil matrix. As the organic matter and phosphate fertilizer were effective in reducing mobility of $\mathrm{Cu}$, the organic matter was more effective in the immobilization of $\mathrm{Cr}$, and inorganic amendment induced the $\mathrm{Zn}$ precipitation, results from this pilot study suggest a combined use of these two amendments for soil remediation strategies. However, liming may be further needed to prevent soil acidification on longer time scales. Also, we propose the use of chemical and biological remediation strategies for potential improvement of effectiveness.
\end{abstract}

\section{Introduction}

Point source and diffuse contamination of soils by heavy metals (HMs) is an environmental problem worldwide. An important input pathway is anthropogenic activities, such as disposal of industrial and hazardous residues, mining activities, incidental accumulations, industries atmospheric deposition, energy generation, and agricultural chemicals $[2,3]$. High proportion of the contamination is retained by soil particles, so that is why this system is considered a vulnerable environment to being contaminated [4]. In addition, there is an increasing interest in HM contamination as a result of a continuous accumulation on top soil, with elevated availability to organisms [5]. Therefore, high concentrations of HM and their potential toxicity may affect soil ecology, agricultural production, and water quality, implicating risks for environment and human health [6].

In Argentine, soil contamination has been mostly recorded in urban and periurban areas. Reference [7] indicated that concentrations of $\mathrm{Cd}, \mathrm{Cu}, \mathrm{Pb}$, and $\mathrm{Zn}$ in urban soils exceeded the international standards referred to the human health, and according to [8], elevated levels of $\mathrm{Cu}, \mathrm{Pb}, \mathrm{Cd}$, and $\mathrm{Zn}$ were found in horticultural soils of Buenos Aires. Contamination with $\mathrm{Cu}, \mathrm{Cr}, \mathrm{Zn}, \mathrm{As}, \mathrm{Cd}, \mathrm{Hg}$, and $\mathrm{Pb}$ occurred near the Ecological Reserve area of Buenos Aires, close to an automobile cemetery. Moreover, industrialized areas are affected by high $\mathrm{Cu}, \mathrm{Zn}$, and $\mathrm{Cr}$ concentrations in industrial effluents [9].

Heavy metals partition in contaminated soils is influenced by several chemical and biological reactions $[10,11]$. Soils retain HM by sorption, precipitation, and complexation; such reactions reduce the metal mobility and bioavailability $[2,12,13]$. However, this natural attenuation process can be complemented by in situ application of chemical technologies, as organic and inorganic amendments [14]. In situ chemical immobilization is a cost-effective remediation approach that stabilizes HM in contaminated soil [15, 16]. Generally, these technologies reduce HM availability, 
TABle 1: Physicochemical characteristics of the Typic Hapludoll soil. All data are expressed as dry basis (DM).

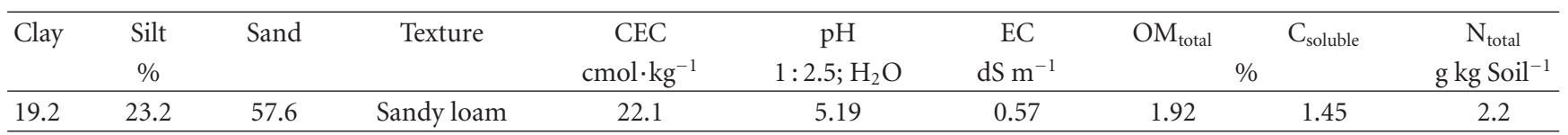

$\mathrm{OM}_{\text {total }}$ : total organic matter; $\mathrm{C}_{\text {soluble: }}$ soluble carbon; $\mathrm{N}_{\text {total }}$ : total nitrogen.

TABle 2: Physical and chemical properties of the Biosolid Compost used as organic amendment. (DM: dry mater).

\begin{tabular}{lccccrr}
\hline $\begin{array}{l}\text { CEC } \\
\left(\mathrm{cmol} \cdot \mathrm{kg}^{-1}\right)\end{array}$ & $\begin{array}{c}\mathrm{pH} \\
\left(1: 2.5 ; \mathrm{H}_{2} \mathrm{O}\right)\end{array}$ & $\begin{array}{c}\mathrm{EC} \\
\mathrm{dS} \mathrm{m}^{-1}\end{array}$ & $\mathrm{OM}_{\text {total }}$ & $\mathrm{C}_{\text {soluble }}$ & $\begin{array}{c}\mathrm{N}_{\text {total }} \\
\left.(\mathrm{g} \mathrm{kg} \mathrm{Soil})^{-1}\right)\end{array}$ \\
\hline 14.3 & 7.5 & 1.29 & 4.25 & 0.031 & 0.32 & 13.2 \\
\hline
\end{tabular}

$\mathrm{OM}_{\text {total }}$ : total organic matter; $\mathrm{C}_{\text {soluble: }}$ : soluble carbon; $\mathrm{N}_{\text {total }}$ : total nitrogen; $\mathrm{C} / \mathrm{N}$ : carbon-nitrogen coeficient.

improve soil fertility, and increase plant growth [17, 18]. On one hand, organic amendments (compost) contain a high proportion of humified organic matter and could decrease HM bioavailability in soil, even though temporally and thus permitting the reestablishment of vegetation [19]. On the other hand, within the inorganic amendments, phosphate fertilizers are also effective in HM immobilization through formation of stable mineral HM phosphate [20]. The formation of these insoluble metal compounds, reduce their mobility through the soil profile and the pool available for biota [21]. In addition, the application of amendments simultaneously, could promote plant growth and biological activity of degraded soil [22].

The objective of this study has been to assess the distribution of three heavy metals $(\mathrm{Cu}, \mathrm{Zn}$, and $\mathrm{Cr}$ ) as a mixture in contaminated soil, after applying biosolid compost (BC) and phosphate fertilizer (PF), both independently and in combination.

\section{Materials and Methods}

2.1. Soil Sampling. Typic Hapludoll soil representative from sandy Pampas $\left(35^{\circ} 37^{\prime} \mathrm{S}, 61^{\circ} 22^{\prime} \mathrm{O}\right.$ ) (Tables 1 and 3 ) was chosen for the experiment. Five composite topsoil samples $(0-20 \mathrm{~cm}$ depth) were randomly collected (10 individual samples). The sampled soil was air-dried and passed through a $2 \mathrm{~mm}$ sieve to obtain homogeneous particle size. Soil samples were enriched by adding metal solutions $\left(\mathrm{CuCl}_{2} 2 \mathrm{H}_{2} \mathrm{O}\right.$, $\mathrm{ZnSO}_{4} 7 \mathrm{H}_{2} \mathrm{O}$, and $\mathrm{H}_{2} \mathrm{CrO}_{4}$ ), achieving final concentrations of $350 \mu \mathrm{g} \mathrm{g}^{-1}$ copper $(\mathrm{Cu}), 700 \mu \mathrm{gg}^{-1}$ zinc $(\mathrm{Zn})$, and $750 \mu \mathrm{g}$ $\mathrm{g}^{-1}$ chromium $(\mathrm{Cr})$. This enrichment overcame the maximum levels of total HM established in agricultural soils by Argentinean legislation (Table 3). Wetting cycles (at field capacity) and air-drying every five days were performed, during a period of three months.

2.2. Greenhouse Experiment. The experiment consisted in $1 \mathrm{~kg}$ pots containing $\mathrm{HM}$-enriched soil and two different amendments: Biosolid Compost (BC) (Tables 2 and 3) as organic amendment and superphosphate triples (PF) as inorganic amendment $\left(100 \mathrm{Mgha}^{-1}\right.$ and $100 \mathrm{~kg} \mathrm{ha}^{-1}$ rate, resp.). The compost was enriched with sawdust as bulking agents and biosolids from sewage sludge treatment plant located in the north of Buenos Aires City (1:1, biosolid: sawdust ratio by volume). Samples of enriched soil were thoroughly mixed with the amendments resulting in four treatments: (i) Contaminated Soil (CSC) as control, (ii) Contaminated Soil + Phosphate Fertilizer $(\mathrm{CSC}+\mathrm{PF})$, (iii) Contaminated Soil + Biosolid Compost $(\mathrm{CSC}+\mathrm{BC})$, and (iv) Contaminated Soil + Phosphate Fertilizer + Biosolid Compost $(\mathrm{CSC}+\mathrm{PF}+\mathrm{BC})$. The experiment was carried out in a completely randomized design with three replications per treatment. Destructive samplings were performed at two time points of the experiment: beginning (0 days) and end (190 days).

2.3. Soil Chemical Analysis. Sequential extraction procedure was performed on all samples from each pot $\left(3 \mathrm{~g}\right.$ in $50 \mathrm{~cm}^{3}$ polypropylene centrifuge tubes) to measure $\mathrm{Cu}, \mathrm{Zn}$, and $\mathrm{Cr}$ in different fractions after the application of BC and PF, separately and simultaneously, according to [23] methodology. This type of procedure has been successfully used for sludgetreated soils [24-26]. The procedure separates metals into four operationally defined fractions: soluble and exchangeable (EX), organic matter bound (OC), carbonate bound (CB), and residual (RES) (Table 4). After each extraction, the solution was separated from the solid by centrifugation at $3000 \mathrm{rpm}$ for $45 \mathrm{~min}$. The supernatant was decanted and filtered through Whatman N. 42 filter paper, and the wet residue in the tube was recorded. The pseudototal HM concentrations were determined by acid digestion with mixture of $\mathrm{HCl}, \mathrm{H}_{2} \mathrm{SO}_{4}$, and $\mathrm{HNO}_{3}$ [1]. Heavy metals contents of each supernatant were measured at two time points by flame atomic absorption spectrophotometer (AAS). Soil pH and electricity conductivity (EC) was measured using a mixture of soil and deionized water $(1: 2.5 \mathrm{~m} / \mathrm{v})$ with a glass electrode [27] in each time point.

2.4. Statistical Analysis. Treatments effects were determined by factorial arrangement of $4 \times 2$ (amendment levels and time points), according to the general linear model procedure of Statistics, version 8.0. Differences between means were separated using least significant differences (LSDs). Variances were stabilized when necessary by a logarithmic transformation of some data set. In addition, a simple linear correlation between these variables was performed. 
TABLE 3: Heavy metals content (in ppm) of soil samples and composted biosolids, and the maximum levels of total heavy metals established by Argentinean law (Hazardous wastes regime: soil quality guide).

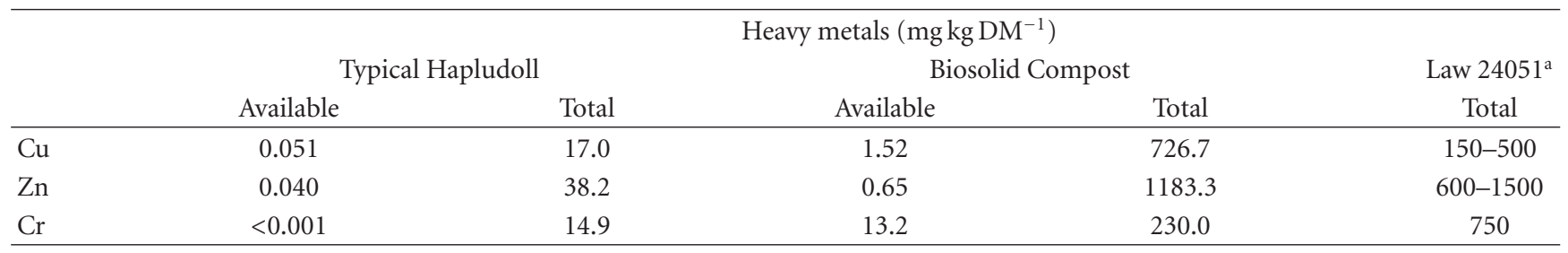

${ }^{a}$ Levels for soils with agricultural and industrial uses.

TABLE 4: Sequential extraction procedure of heavy metals from soil samples and operationally defined fractions.

\begin{tabular}{|c|c|c|c|}
\hline Phase/association & Abbr. & Step & Operational procedure \\
\hline Soluble_-exchangeable & EX & 1 & $30 \mathrm{~mL} 0.1 \mathrm{M} \mathrm{CaCl}_{2}$, shaken $16 \mathrm{~h}$ at room temperature \\
\hline Organic matter-bound & OB & 2 & $30 \mathrm{~mL} 0.5 \mathrm{M} \mathrm{NaOH}$, shaken $16 \mathrm{~h}$ at room temperature \\
\hline Carbonates_-bound & $\mathrm{CB}$ & 3 & $30 \mathrm{~mL} 0.5 \mathrm{M} \mathrm{Na}_{2}$ EDTA, shaken $1 \mathrm{~h}$ \\
\hline Residual & RES & 4 & $\begin{array}{l}\text { Estimated by summation of three fractions and the total content (acid digestion } \\
\text { with hydrochloric, sulfuric, and nitric acids) [1] }\end{array}$ \\
\hline
\end{tabular}

\section{Results and Discussion}

3.1. Distribution of HM in Soil Fractions. The distribution of $\mathrm{Cu}, \mathrm{Zn}$, and $\mathrm{Cr}$ in contaminated and remediated soils for both sampling dates is reported in Table 5. Heavy metals in contaminated and amended soils showed similar pattern of distribution between fractions. Furthermore, each metal was associated in a different way with soil components, as was expected. These differential trends are in agreement with other studies, which demonstrate that the adsorption process is metal specific $[28,29]$.

In particular, copper was mainly associated with soil organic matter (Table $5(\mathrm{~b}))(P<0.001)$, forming that make metals less available for plants [30]. Copper-organic matter association was slightly higher at the end of the experiment, especially with biosolid compost application (among 4 to $6 \%$ ) in comparison with the other treatments. In agreement with [31], extraction procedure showed that in contaminated soils $\mathrm{Cu}$ was mostly present in the acid-soluble and reducible fractions, and in soil amendment with organic matter the soluble and exchangeable $\mathrm{Cu}$ fraction was reduced. A possible explanation for this result is the precipitation and complexation by the presence of stabilized organic matter in the compost, such as humic substances (Table 2) [16, 32]. These results corroborate other investigator findings which indicated that organic matter plays a fundamental role in controlling soil HM adsorption, being $\mathrm{Cu}$ the preferentially associated with the organic fraction [33]. On the other hand, [34] reported that extractable amounts of $\mathrm{Cu}$ were always very small, indicating a low contribute from soluble organic $\mathrm{Cu}$ complexes. However, in this pilot study the amount of $\mathrm{Cu}-\mathrm{EX}$ was lower than $1 \%$ of total heavy metal content, and at the end of the experiment, compost and $\mathrm{BC}+\mathrm{PF}$ treatments had more $\mathrm{Cu}$ in residual fraction, indicating greater $\mathrm{Cu}$ immobilization.

In all treatments, $\mathrm{Zn}$ was remained mostly in soluble and exchangeable fraction of soil as mobile $\mathrm{Zn}(P<0.001)$.
In contaminated soil without amendments (CSC) and with fertilizer application, $\mathrm{Zn}$ solubility increased by 15.4 and $8.4 \%$, respectively, with experiment time. These results differ with [35], who demonstrated that leached $\mathrm{Zn}$ concentration decreased $5.92 \pm 2.74 \mathrm{mg} \mathrm{kg}^{-1}$ with phosphate amendment, as a result of immobilization by metal-phosphate precipitates. However, our results are in agreement with those of other studies, which confirm that this increase was possible associated with soil acidification [16, 36, 37]. It cannot be excluded that the simultaneous adding of metal cations could affect $\mathrm{Zn}$ adsorption, in agreement with [38], due to ionic competition between $\mathrm{Zn}, \mathrm{Cu}$, and $\mathrm{Cr}$ [8]. Metals with high water solubility pose higher risk of leaching into groundwater. In fact, [39] established that, according to maximum leached concentrations (as a fraction of the total concentration in soil), $\mathrm{Zn}$ was the most mobile element in a sequence composite by $\mathrm{Zn}, \mathrm{Cu}$, As, and $\mathrm{Cr}$. As a consequence, $\mathrm{Zn}$ may offer major environmental risk compared to other metals, since mobile $\mathrm{Zn}$ is immediately available for absorption by plants and soil biota in accordance [40, 41].

Chromium was initially adsorbed by soil carbonates as compared with soil organic matter $(P<0.001)[42,43]$. In contrast, at the end of the experiment, a $\mathrm{Cr}$ redistribution among fractions was observed and the $\mathrm{Cr}$ fraction organic associated to the soil organic matter increased by $10 \%$ in the $\mathrm{BC}$ treatment, as compared to the beginning of the experiment. This suggests that the addition of organic amendments could enhance the reduction rate of $\mathrm{Cr}$ (VI) to $\mathrm{Cr}$ (III) increasing it temporal immobilization in soil [44]. According to [34] $\mathrm{Cr}$ amounts associated with organic matter increase with the increasing extent of soil contamination, thereby suggesting high constants values of organic-Cr complexes. Moreover, these authors demonstrated that $\mathrm{Cr}$ undergoes a progressive insolubilization (organically bound $\mathrm{Cr}$ into insoluble $\mathrm{Cr}$ ) in about 20 years. In this pilot experiment we cannot corroborate this ageing process due to the soil metal spiking approach and the relatively short incubation time. 
TABLE 5: Distribution of copper (a), zinc (b), and chromium (c) in soil chemical fractions at two time points of the experiment: beginning (A) and end (B). Treatments: CSC: Contaminated Soil, CSC + PF: Contaminated Soil + Phosphate Fertilizer, CSC + BC: Contaminated Soil + Biosolid Compost, and CSC + PF + BC: Contaminated Soil + Phosphate Fertilizer + Biosolid Compost (Mean \pm S.D., $n=3$ ).

(a)

\begin{tabular}{|c|c|c|c|}
\hline \multirow{2}{*}{ Soluble and exchangeable } & \multicolumn{3}{|c|}{ Heavy metals concentration $\left(\mathrm{mg} \mathrm{kg}^{-1}\right)$} \\
\hline & $\mathrm{Cu}$ & $\mathrm{Zn}$ & $\mathrm{Cr}$ \\
\hline $\operatorname{CsC}(\mathrm{A})$ & $2.56 \pm 0.8$ & $553.00 \pm 2.6$ & $0.27 \pm 0.0$ \\
\hline $\operatorname{CSC}(\mathrm{B})$ & $4.25 \pm 0.5$ & $457.00 \pm 47.6$ & $0.54 \pm 0.1$ \\
\hline $\mathrm{CSC}+\mathrm{PF}(\mathrm{A})$ & $4.70 \pm 2.4$ & $569.33 \pm 77.5$ & $0.53 \pm 0.0$ \\
\hline $\mathrm{CSC}+\mathrm{PF}(\mathrm{B})$ & $5.14 \pm 2.7$ & $438.17 \pm 77.9$ & $0.64 \pm 0.2$ \\
\hline $\mathrm{CSC}+\mathrm{BC}(\mathrm{A})$ & $3.72 \pm 0.3$ & $547.67 \pm 67.2$ & $0.43 \pm 0.0$ \\
\hline $\mathrm{CSC}+\mathrm{BC}(\mathrm{B})$ & $3.75 \pm 1.0$ & $426.17 \pm 68.0$ & $0.50 \pm 0.5$ \\
\hline $\mathrm{CSC}+\mathrm{PF}+\mathrm{BC}(\mathrm{A})$ & $4.76 \pm 0.7$ & $557.33 \pm 19.0$ & $0.62 \pm 0.1$ \\
\hline $\mathrm{CSC}+\mathrm{PF}+\mathrm{BC}(\mathrm{B})$ & $4.95 \pm 0.4$ & $422.67 \pm 23.1$ & $0.79 \pm 0.2$ \\
\hline
\end{tabular}

\section{ANOVA}

Amendments

Moment

Amendments $\times$ moment

ns

ns

(b)

Organic matter bound

$\operatorname{CSC}(\mathrm{A})$

CSC (B)

$\mathrm{CSC}+\mathrm{PF}(\mathrm{A})$

$\mathrm{CSC}+\mathrm{PF}(\mathrm{B})$

$\mathrm{CSC}+\mathrm{BC}(\mathrm{A})$

$\mathrm{CSC}+\mathrm{BC}(\mathrm{B})$

$\mathrm{CSC}+\mathrm{PF}+\mathrm{BC}(\mathrm{A})$

$\mathrm{CSC}+\mathrm{PF}+\mathrm{BC}(\mathrm{B})$

\section{ANOVA}

Amendments

Moment

Amendments $\times$ moment ns

$\mathrm{Cu}$

$183.27 \pm 16.3$

$200.73 \pm 7.2$

$186.20 \pm 12.6$

$199.93 \pm 18.7$

$196.93 \pm 13.4$

$206.30 \pm 16.3$

$202.00 \pm 10.1$

$189.80 \pm 3.7$
Heavy metals concentration $\left(\mathrm{mg} \mathrm{kg}^{-1}\right)$

$195.17 \pm 6.7$

$115.73 \pm 0.6$

$141.33 \pm 25.0$

$110.80 \pm 26.0$

$193.33 \pm 63.1$

$140.20 \pm 31.5$

$172.50 \pm 13.5$

$126.20 \pm 20.9$
$\mathrm{Cr}$

$32.63 \pm 6.6$

$57.48 \pm 2.9$

$32.20 \pm 2.7$

$52.15 \pm 10.6$

$34.20 \pm 7.4$

$45.57 \pm 6.9$

$28.87 \pm 2.8$

$39.70 \pm 0.8$

(c)

Carbonate bound

Heavy metals concentration $\left(\mathrm{mg} \mathrm{kg}^{-1}\right)$

\begin{tabular}{lccr} 
& $\mathrm{Cu}$ & $\mathrm{Zn}$ & $\mathrm{Cr}$ \\
\hline CSC (A) & $189.20 \pm 12.6$ & $330.33 \pm 29.5$ & $139.47 \pm 5.1$ \\
CSC (B) & $183.97 \pm 17.1$ & $199.83 \pm 19.3$ & $152.13 \pm 2.8$ \\
CSC + PF (A) & $183.90 \pm 2.5$ & $340.67 \pm 111.6$ & $138.20 \pm 9.0$ \\
CSC + PF (B) & $166.73 \pm 10.8$ & $197.17 \pm 29.5$ & $143.83 \pm 14.3$ \\
CSC + BC (A) & $190.53 \pm 11.3$ & $334.00 \pm 84.3$ & $123.73 \pm 14.6$ \\
CSC + BC (B) & $150.85 \pm 11.6$ & $234.67 \pm 26.3$ & $145.95 \pm 0.9$ \\
CSC + PF + BC (A) & $187.20 \pm 9.8$ & $317.67 \pm 9.7$ & $115.93 \pm 11.6$ \\
CSC + PF + BC (B) & $162.30 \pm 8.9$ & $242.33 \pm 44.7$ & $143.47 \pm 4.3$ \\
\hline
\end{tabular}

ANOVA

Amendments

Moment

Amendments $\times$ moment

ns

ns

ns 
(d)

\begin{tabular}{|c|c|c|c|}
\hline \multirow{2}{*}{ Residual } & \multicolumn{3}{|c|}{ Heavy metals concentration $\left(\mathrm{mg} \mathrm{kg}^{-1}\right)$} \\
\hline & $\mathrm{Cu}$ & $\mathrm{Zn}$ & $\mathrm{Cr}$ \\
\hline $\operatorname{CSC}(\mathrm{A})$ & $29.25 \pm 2.5$ & $39.6 \pm 12.2$ & $446.8 \pm 1.0$ \\
\hline CSC (B) & $20.76 \pm 3.2$ & $30.2 \pm 5.8$ & $466.28 \pm 2.6$ \\
\hline $\mathrm{CSC}+\mathrm{PF}(\mathrm{A})$ & $20.1 \pm 8.3$ & $123.4 \pm 39.6$ & $469.5 \pm 6.0$ \\
\hline $\mathrm{CSC}+\mathrm{PF}(\mathrm{B})$ & $39.52 \pm 17.1$ & $28.52 \pm 5.6$ & $616.02 \pm 14.4$ \\
\hline $\mathrm{CSC}+\mathrm{BC}(\mathrm{A})$ & $32.8 \pm 14.4$ & $113.2 \pm 38.6$ & $476.3 \pm 12.4$ \\
\hline $\mathrm{CSC}+\mathrm{BC}(\mathrm{B})$ & $50.18 \pm 0.8$ & $63.21 \pm 2.6$ & $496.43 \pm 4.1$ \\
\hline $\mathrm{CSC}+\mathrm{PF}+\mathrm{BC}(\mathrm{A})$ & $31.2 \pm 5.5$ & $55.0 \pm 4.4$ & $431.5 \pm 6.0$ \\
\hline $\mathrm{CSC}+\mathrm{PF}+\mathrm{BC}(\mathrm{B})$ & $45.67 \pm 4.3$ & $39.99 \pm 28.5$ & $543.13 \pm 2.4$ \\
\hline \multicolumn{4}{|l|}{ ANOVA } \\
\hline Amendments & $*$ & & * \\
\hline Moment & $*$ & & * \\
\hline Amendments $\times$ moment & ns & ns & $*$ \\
\hline
\end{tabular}

Significance levels: $P<0.05$; ns: not significant.

According to [45] and assuming that mobility and availability of $\mathrm{Cu}, \mathrm{Zn}$, and $\mathrm{Cr}$ are associated with their solubility and geochemical forms and that these HMs reduce in the order of extraction sequence, the apparent mobility and potential availability in the soil were $\mathrm{Zn}>\mathrm{Cu}>\mathrm{Cr}$. In addition, [46] reported that in carbonate soils $\mathrm{Cr}, \mathrm{Cu}$, and $\mathrm{Pb}$ had higher affinity for the reactive solid phases than $\mathrm{Ni}$, $\mathrm{Zn}$ and $\mathrm{Cd}$. The active role of amorphous $\mathrm{Al}$ silicates and interaction between clays and organic matter from compost, with formation of organoclays, would have improved the soil adsorbing capacity and enhanced this HM competition [34].

3.2. Effect of Amendments Application on Soil Chemical Characteristics. Application of amendments improved the soil chemical characteristics (Figure 1). Initially, soil pH increased with the addition of both amendments, compared to untreated soil. Since these results were in agreement with those found in a previous study [47], this soil $\mathrm{pH}$ modification was slight $(2.87 \%=\mathrm{BC}$ and $2.87 \%=\mathrm{PF})$, and there was no correlation with HM bioavailability [48]. Soil acidification observed upon increasing of the experiment time for all treatments was possibly due to soil organic matter mineralization [49] and/or to $\mathrm{H}+$ formation by the fertilizer solubilization [50]. Therefore, liming may be necessary to compensate potential soil acidification when using $\mathrm{PF}$ and $\mathrm{BC}$ application to reduce HM-contaminated soil [51]. Contrary to [52], we found that soil EC decreased significantly when organic amendment was added $(P=$ 0.044 ), at the end of the experiment, and no correlation was found between the EC and heavy metals availability.

\section{Conclusions}

Results from this pilot experiment, showed that application of $\mathrm{BC}$ and $\mathrm{PF}$ in combination affected the partition of $\mathrm{Cr}, \mathrm{Cu}$, and $\mathrm{Zn}$ added to soil. In particular, $\mathrm{BC}$ and $\mathrm{PF}$ in combination reduced the solubility and mobility of $\mathrm{Cu}$
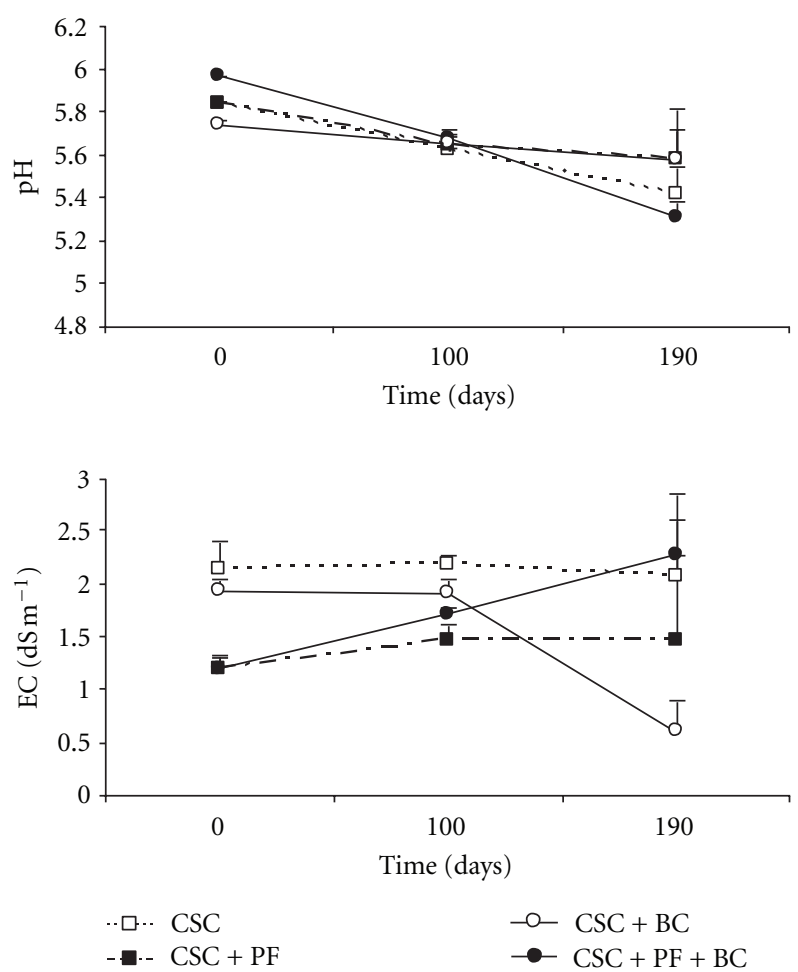

FIgURE 1: Changes in chemical characteristics of contaminated and organic and inorganic remediated soil, respect to assay time. Treatments: $\mathrm{CSC}=$ Contaminated Soil, $\mathrm{CSC}+\mathrm{PF}=$ Contaminated Soil + Phosphate Fertilizer, CSC + BC $=$ Contaminated Soil + Biosolid Compost, and CSC $+\mathrm{PF}+\mathrm{BC}=$ Contaminated Soil + Phosphate Fertilizer + Biosolid Compost. The bars indicate Standard Error of the data.

and $\mathrm{Cr}$ whereas $\mathrm{Zn}$ stabilization was increased through compost with or without PF application. The use of PF alone increased the available $\mathrm{Zn}$. These results show that combination of organic and inorganic amendments are needed for immobilizing different metals of concern and 
could provide a basis for future research about the existence of interactions between metals added simultaneously into the soil. However, the use of liming agents may be needed to buffer soil acidification on prolonged time scales.

\section{References}

[1] S. P. McGrath and C. H. Cunliffe, "A simplified method for the extraction of the metals $\mathrm{Fe}, \mathrm{Zn}, \mathrm{Cu}, \mathrm{Ni}, \mathrm{Pb}, \mathrm{Cr}, \mathrm{Co}$ and $\mathrm{Mn}$ from soils and sewage sludges," Journal of the Science of Food and Agriculture, vol. 36, pp. 794-798, 1985.

[2] A. Kabata-Pendias, Trace Elements in Soils and Plants, CRC Press, Boca Raton, Fla, USA, 3rd edition, 2000.

[3] R. Schulin, F. Curchod, M. Mondeshka, A. Daskalova, and A. Keller, "Heavy metal contamination along a soil transect in the vicinity of the iron smelter of Kremikovtzi (Bulgaria)," Geoderma, vol. 140, no. 1-2, pp. 52-61, 2007.

[4] D. T. Pinochet, J. A. Aguirre, and E. R. Quiroz, "Estudio de la lixiviación de Cadmio, Mercurio y Plomo en suelos derivados de cenizas volcánicas," Agro Sur, vol. 30, no. 1, pp. 51-58, 2002.

[5] D. C. Adriano, Trace Elements in Terrestrial Environments: Biogeochemistry, Bioavailability and Risks of Metals, Springer, New York, NY, USA, 2nd edition, 2001.

[6] J. A. Gómez del Río, P. J. Morando, and D. S. Cicerone, "Natural materials for treatment of industrial effluents: Comparative study of the retention of $\mathrm{Cd}, \mathrm{Zn}$ and Co by calcite and hydroxyapatite. Part I: batch experiments," Journal of Environmental Management, vol. 71, no. 2, pp. 169-177, 2004.

[7] R. S. Lavado, M. B. Rodrígue, J. D. Scheiner et al., "Heavy metals in soils of Argentina: comparison between urban and agricultural soils," Communications in Soil Science and Plant Analysis, vol. 29, no. 11-14, pp. 1913-1917, 1998.

[8] L. Giuffré, S. Ratto, L. Marbán, J. Schonwald, and R. Romaniuk, "Heavy metals risk in urban agriculture," Ciencia del Suelo, vol. 23, no. 1, pp. 101-106, 2005.

[9] K. Flogeac, E. Guillon, and M. Aplincourt, "Competitive sorption of metal ions onto a north-eastern France soil. Isotherms and XAFS studies," Geoderma, vol. 139, no. 1-2, pp. 180-189, 2007.

[10] M. B. McBride, Environmental Chemistry of Soils, Oxford University Press, New York, NY, USA, 1994.

[11] P. Sipos, T. Németh, V. K. Kis, and I. Mohai, "Sorption of copper, zinc and lead on soil mineral phases," Chemosphere, vol. 73, no. 4, pp. 461-469, 2008.

[12] A. P. D. Mora, J. J. Ortega-Calvo, F. Cabrera, and E. Madejón, "Changes in enzyme activities and microbial biomass after "in situ" remediation of a heavy metal-contaminated soil," Applied Soil Ecology, vol. 28, no. 2, pp. 125-137, 2005.

[13] R. Clemente, D. J. Walker, and M. P. Bernal, "Uptake of heavy metals and As by Brassica juncea grown in a contaminated soil in Aznalcóllar (Spain): the effect of soil amendments," Environmental Pollution, vol. 138, no. 1, pp. 46-58, 2005.

[14] M. Mench, J. Vangronsveld, C. Beckx, and A. Ruttens, "Progress in assisted natural remediation of an arsenic contaminated agricultural soil," Environmental Pollution, vol. 144, no. 1, pp. 51-61, 2006.

[15] O. P. Shukla, U. N. Rai, and S. Dubey, "Involvement and interaction of microbial communities in the transformation and stabilization of chromium during the composting of tannery effluent treated biomass of Vallisneria spiralis L," Bioresource Technology, vol. 100, no. 7, pp. 2198-2203, 2009.

[16] X. Cao, A. Wahbi, L. Ma, B. Li, and Y. Yang, "Immobilization of $\mathrm{Zn}, \mathrm{Cu}$, and $\mathrm{Pb}$ in contaminated soils using phosphate rock and phosphoric acid," Journal of Hazardous Materials, vol. 164, no. 2-3, pp. 555-564, 2009.

[17] N. Calace, T. Campisi, A. Iacondini, M. Leoni, B. M. Petronio, and M. Pietroletti, "Metal-contaminated soil remediation by means of paper mill sludges addition: chemical and ecotoxicological evaluation," Environmental Pollution, vol. 136, no. 3, pp. 485-492, 2005.

[18] R. Clemente, C. Almela, and M. P. Bernal, "A remediation strategy based on active phytoremediation followed by natural attenuation in a soil contaminated by pyrite waste," Environmental Pollution, vol. 143, no. 3, pp. 397-406, 2006.

[19] P. Castaldi and P. Melis, "Growth and yield characteristics and heavy metals content on tomatoes in different growing media," Communications in Soil Science and Plant Analysis, vol. 35, no. 1-2, pp. 85-98, 2004.

[20] J. Wright, J. L. Conca, and A. F. Slater, "PIMS with apatite II: a field scale demonstration on a lead contaminated soil," in Stabilisation/Solidification Treatment and Remediation, A. Al-Tabbaa and J. A. Stegemann, Eds., Chapter 4, Taylor and Francis, London, UK, 2005.

[21] W. Geebelen, D. C. Adriano, D. Van Der Lelie et al., "Selected bioavailability assays to test the efficacy of amendment-induced immobilization of lead in soils," Plant and Soil, vol. 249, no. 1, pp. 217-228, 2003.

[22] E. Madejón, A. P. De Mora, E. Felipe, P. Burgos, and F. Cabrera, "Soil amendments reduce trace element solubility in a contaminated soil and allow regrowth of natural vegetation," Environmental Pollution, vol. 139, no. 1, pp. 40-52, 2006.

[23] S. P. McGrath and J. Cegarra, "Chemical extractability of heavy metals during and after long-term applications of sewage sludge to soil," Journal of Soil Science, vol. 43, no. 2, pp. 313321, 1992.

[24] A. K. Alva, B. Huang, and S. Paramasivam, "Soil pH affects copper fractionation and phytotoxicity," Soil Science Society of America Journal, vol. 64, no. 3, pp. 955-962, 2000.

[25] S. Amir, M. Hafidi, G. Merlina, and J. C. Revel, "Sequential extraction of heavy metals during composting of sewage sludge," Chemosphere, vol. 59, no. 6, pp. 801-810, 2005.

[26] S. I. Torri and R. Lavado, "Zinc distribution in soils amended with different kinds of sewage sludge," Journal of Environmental Management, vol. 88, no. 4, pp. 1571-1579, 2008.

[27] N. T. Faithfull, Methods in Agricultural Chemicals Analysis: A Practical Handbook, CAB International Publishing, Wallingford, UK, 2004.

[28] G. Welp and G. W. Brümmer, "Adsorption and solubility of ten metals in soil samples of different composition," Journal of Plant Nutrition and Soil Science, vol. 162, no. 2, pp. 155-161, 1999.

[29] P. C. Gomes, M. P. F. Fontes, A. G. Da Silva, E. S. De Mendonça, and A. R. Netto, "Selectivity sequence and competitive adsorption of heavy metals by Brazilian soils," Soil Science Society of America Journal, vol. 65, no. 4, pp. 1115-1121, 2001.

[30] N. A. Ali, M. Ater, G. I. Sunahara, and P. Y. Roubidoux, "Phytotoxicity and bioaccumulation of cooper and chromium using barley (Hordeum vulgar L.) in spiked artificial and natural forest soils," Ecotoxicology and Environmental Safety, vol. 54, pp. 363-374, 2004.

[31] A. Lagomarsino, M. Mench, R. Marabottini et al., "Copper distribution and hydrolase activities in a contaminated soil amended with dolomitic limestone and compost," Ecotoxicology and Environmental Safety, vol. 74, no. 7, pp. 2013-2019, 2011.

[32] R. O'Dell, W. Silk, P. Green, and V. Claassen, "Compost amendment of $\mathrm{Cu}-\mathrm{Zn}$ minespoil reduces toxic bioavailable 
heavy metal concentrations and promotes establishment and biomass production of Bromus carinatus (Hook and Arn.)," Environmental Pollution, vol. 148, no. 1, pp. 115-124, 2007.

[33] S. Dragović, N. Mihailović, and B. Gajić, "Heavy metals in soils: distribution, relationship with soil characteristics and radionuclides and multivariate assessment of contamination sources," Chemosphere, vol. 72, no. 3, pp. 491-495, 2008.

[34] P. Adamo, M. Zampella, L. Gianfreda, G. Renella, F. A. Rutigliano, and F. Terribile, "Impact of river overflowing on trace element contamination of volcanic soils in south Italy: Part I. Trace element speciation in relation to soil properties," Environmental Pollution, vol. 144, no. 1, pp. 308-316, 2006.

[35] F. Panfili, A. Manceau, G. Sarret et al., "The effect of phytostabilization on $\mathrm{Zn}$ speciation in a dredged contaminated sediment using scanning electron microscopy, X-ray fluorescence, EXAFS spectroscopy, and principal components analysis," Geochimica et Cosmochimica Acta, vol. 69, no. 9, pp. 22652284, 2005.

[36] N. T. Basta and J. J. Sloan, "Application of alkaline biosolids to acid soils: changes in solubility and bioavailability of heavy metals," Journal of Environmental Quality, vol. 28, pp. 633638, 1999.

[37] S. Torri and R. Lavado, "Plant absorption of trace elements in sludge amended soils and correlation with soil chemical speciation," Journal of Hazardous Materials, vol. 166, no. 2-3, pp. 1459-1465, 2009.

[38] M. P. F. Fontes and P. C. Gomes, "Simultaneous competitive adsorption of heavy metals by the mineral matrix of tropical soils," Applied Geochemistry, vol. 18, no. 6, pp. 795-804, 2003.

[39] J. Kumpiene, I. Castillo Montesinos, A. Lagerkvist, and C. Maurice, "Evaluation of the critical factors controlling stability of chromium, copper, arsenic and zinc in iron-treated soil," Chemosphere, vol. 67, no. 2, pp. 410-417, 2007.

[40] A. Fuentes, M. Lloréns, J. Sáez, Ma. I. Aguilar, J. F. Ortuño, and V. F. Meseguer, "Phytotoxicity and heavy metals speciation of stabilised sewage sludges," Journal of Hazardous Materials, vol. 108, no. 3, pp. 161-169, 2004.

[41] M. Pueyo, J. Mateu, A. Rigol, M. Vidal, J. F. López-Sánchez, and G. Rauret, "Use of the modified BCR three-step sequential extraction procedure for the study of trace element dynamics in contaminated soils," Environmental Pollution, vol. 152, no. 2, pp. 330-341, 2008.

[42] S. Smith, P. J. Peterson, and K. H. M. Kwan, "Chromium accumulation, transport and toxicity in plants," Toxicological and Environmental Chemistry, vol. 24, pp. 241-251, 1989.

[43] E. F. Covelo, F. A. Vega, and M. L. Andrade, "Simultaneous sorption and desorption of $\mathrm{Cd}, \mathrm{Cr}, \mathrm{Cu}, \mathrm{Ni}, \mathrm{Pb}$, and $\mathrm{Zn}$ in acid soils. II. Soil ranking and influence of soil characteristics," Journal of Hazardous Materials, vol. 147, no. 3, pp. 862-870, 2007.

[44] N. S. Bolan and V. P. Duraisamy, "Role of inorganic and organic soil amendments on immobilisation and phytoavailability of heavy metals: a review involving specific case studies," Australian Journal of Soil Research, vol. 41, no. 3, pp. 533-555, 2003.

[45] L. Q. Ma and G. N. Rao, "Chemical fractionation of cadmium, copper, nickel, and zinc in contaminated soils," Journal of Environmental Quality, vol. 26, no. 1, pp. 259-264, 1997.

[46] A. L. Lafuente, C. González, J. R. Quintana, A. Vázquez, and A. Romero, "Mobility of heavy metals in poorly developed carbonate soils in the Mediterranean region," Geoderma, vol. 145, no. 3-4, pp. 238-244, 2008.

[47] A. Branzini, M. S. Zubillaga, and M. M. Zubillaga, "Microbial response to the application of amendments in a contaminated soil with trace elements," American Journal of Environmental Sciences, vol. 5, no. 1, pp. 94-98, 2009.

[48] P. Tume, J. Bech, L. Longan, L. Tume, F. Reverter, and B. Sepulveda, "Trace elements in natural surface soils in Sant Climent (Catalonia, Spain),” Ecological Engineering, vol. 27, no. 2, pp. 145-152, 2006.

[49] M. De Nobili, G. Cercignani, L. Leita, and P. Sequi, "Evaluation of organic matter stabilization in sewage sludge," Communications in Soil \& Plant Analysis, vol. 17, no. 10, pp. 11091119, 1986.

[50] M. S. Zubillaga and R. S. Lavado, "Long term phosphate fertilization and trace element contents in a Typic Argiudoll of the Rolling Pampas," Ciencia del Suelo, vol. 20, no. 2, pp. 110-113, 2002.

[51] B. Wang, Z. Xie, J. Chen, J. Jiang, and Q. Su, "Effects of field application of phosphate fertilizers on the availability and uptake of lead, zinc and cadmium by cabbage (Brassica chinensis L.) in a mining tailing contaminated soil," Journal of Environmental Sciences, vol. 20, no. 9, pp. 1109-1117, 2008.

[52] I. Sastre-Conde, J. G. Cabezas, A. Guerrero, M. Á. Vicente, and M. D. C. Lobo, "Evaluation of the soil biological activity in a remediation soil assay using organic amendments and vegetal cover," Science of the Total Environment, vol. 378, no. 1-2, pp. 205-208, 2007. 

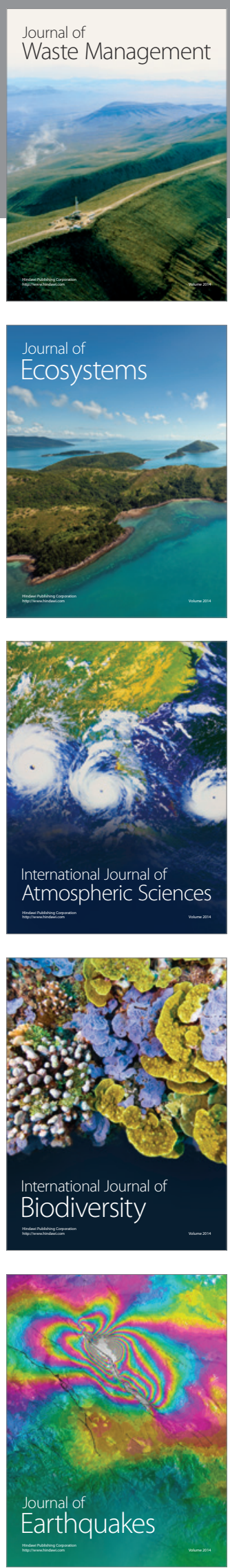
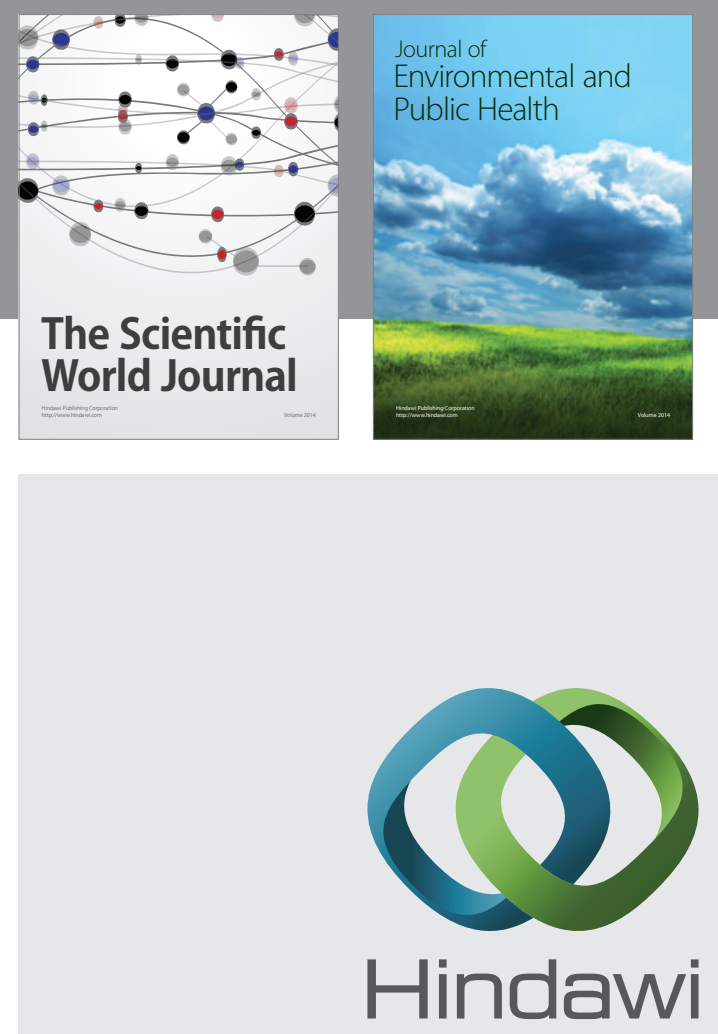

Submit your manuscripts at

http://www.hindawi.com
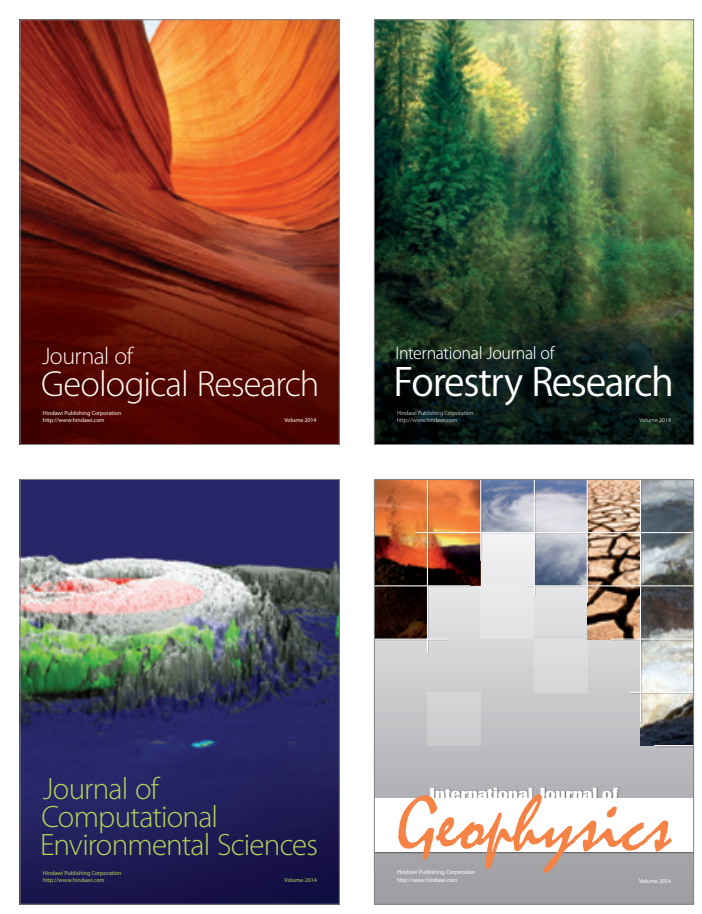
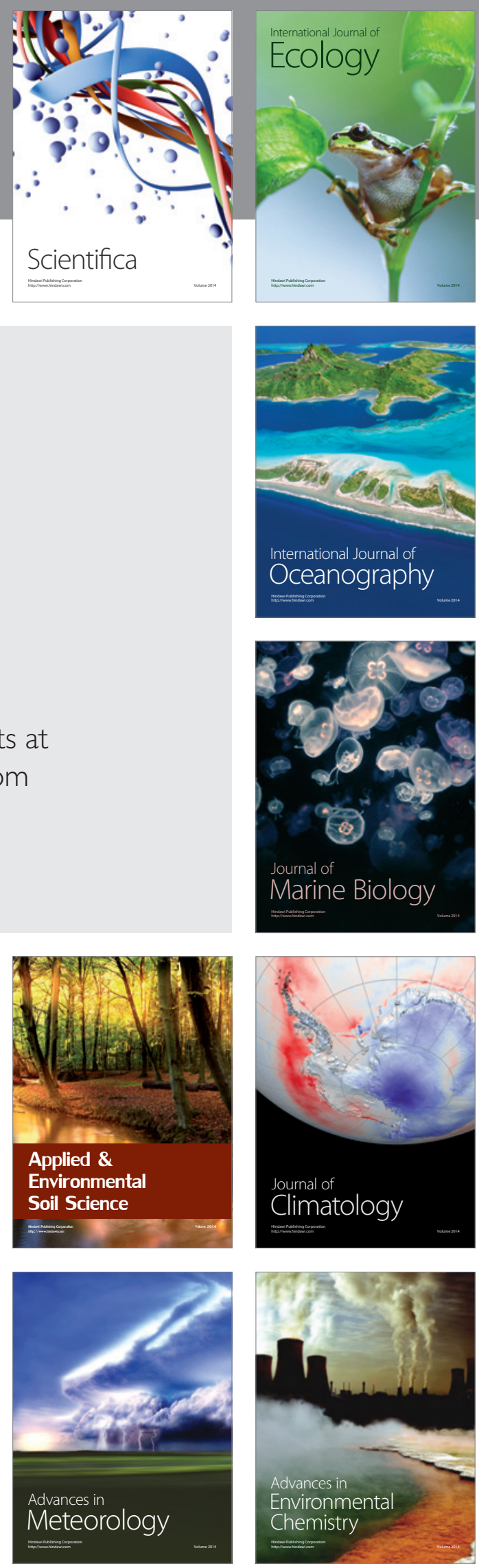